\title{
KAJIAN GENDER TERHADAP PELUANG USAHA DI WEB: PERILAKU INFORMASI PADA MASYARAKAT DESA GIRIMULYA KECAMATAN CIBUNGBULANG KABUPATEN BOGOR
}

\author{
Ade Abdul Hak \\ Univesitas Islam Negeri (UIN) Syarif Hidayatullah Jakarta \\ E-mail: ade71@uinjkt.ac.id
}

\begin{abstract}
Abstrak: This research investigated the differences of information behavior between men and women in Girimulya, Cibungbulang, Bogor. It is important to know the effectiveness of the "WEB desa" as one of information resources of business opportunities. It has been developed by UIN students as one of KKN programs. The approach used in this research was TAM model that was based on the constructs of perceived ease of use (PEOU), perceived usefulness (PU), and behavioral intention (BI). Questionnaires of 100 samples (50 men and 50 women) collected with the random sampling approach were analysed using SPSS version 22. The result showed that the mean score for all of the constructs was high out of maximum score obtainable of 4 (very high), except to the behavioral intention (BI)which was very high and still different to men's was higher than women's. T-Test analysis indicated that there was positive and significant effect for each construct, except the perceived ease of use (PEOU)to the behavioral intention (BI). Meanwhile, the most occurred in the effect value of the women's were higher than men. The usefulness becomes more important than easiness in providing "WEB desa".
\end{abstract}

Kata Kunci: Information Behavior, Gender, "WEB desa”, Technology Acceptance Model(TAM)

\section{PENDAHULUAN}

Permasalahan gender memang sudah cukup lama menjadi isu global, tidak terkecuali di Indonesia. Salah satu isu yang sering muncul di antaranya kesetaraan gender dan pemberdayaan perempuan dalam upaya untuk mewujudkan pembangunan yang dapat dinikmati secara adil, efektif dan akuntable oleh seluruh penduduk Indonesia.

Terkait kesetaraan gender dalam mewujudkan pembangunan bangsa ini, tentu saja tidak akan terlepas dari peluang yang sama terhadap akses informasi isu-isu rencana pembangunan ekonomi baik dalam lingkup mikro maupun makro. Hal ini sejalan dengan Instruksi Preseiden (Inpres) No. 9 Tahun 2000 tentang Pengarustamaan Gender (PUG) dalam
Pembangunan Nasional. Dengan PUG maka semua program pembangunan dapat dilaksanakan dengan mempertimbangankan kesempatan akses perempuan terhadap program pembangunan, serta dengan adanya kendali dan manfaat untuk perempuan (Saraswati, 2013)

Penerapan PUG ini akan menghasilkan kebijakan publik yang lebih efektif untuk mewujudkan pembangunan yang lebih adil dan merata. Salah satu contoh lembaga yang didesain oleh pendahulunya untuk menjadi contoh bagaimana permasalahan gender bisa diatasi adalah BPPT. Tidak ada pembedaan antara perempuan dan laki-laki di lingkungan BPPT. Bahkan beberapa produk karya BPPT yang fenomenal dihasilkan oleh perekayasa perempuan, seperti pengembangan produk 
olahan jamur, pangan darurat dan fuelcell (Iskandar, 2012).

Kunci keberhasilan dalam mendapatkan isu-isu tersebut adalah adanya sumber informasi dari institusi atau perorangan yang mendapatkan kepercayaan dari masyarakat sebagai stackholdernya. Harapan akan adanya penerapan dan pemasyarakatan teknologi untuk mendukung pembangunan yang responsif gender salah satunya tertuju pada ketersediaan WEB yang bisa dikelola oleh institusi pemerintahan yang paling dekat dengan masyarakat, yaitu Desa.

Untuk pemenuhan kebutuhan informasi WEB desa yang dapat diakses oleh masyarakatnya, salah satu kelompok KKN di desa Girimulya telah mencoba membangun WEB desa sebagai salah satu bentuk pengabadian yang dilakukan atas bantuan dana institusinya, UIN Syarif Hidayatullah Jakarta. Pengembangan WEB desa ini diharapkan akan menjadikan sarana untuk mendapatkan informasi peluang usaha di desa tersebut yang dapat diakses oleh masyarakat kapan saja dan di mana saja.

Desa Girimulya terletak di kecamatan Cibungbulang, kabupaten Bogor. Desa ini terletak di dataran rendah 235 Meter dari permukaan laut dan memiliki suhu udara ratarata $23 \mathrm{~s} / \mathrm{d} 32^{\circ} \mathrm{C}$. Desa Girimulya memiliki 3 Dusun, 8 Rukun Warga, dan 30 Rukun Tetanggadengan jumlah penduduk sebanyak 8.631 jiwa, laki-laki 4.517 jiwa dan 4.361 jiwa penduduknya adalah perempuan.Sedangkan jumlah kepala keluarganya sebanyak 2.571 KK.Berdasarkan kelompok usia pendidikan yaitu usia 0-19 tahun ke atas, terdapat 4049 orang, sedangkan berdasarkan kelompok usia tenaga kerja yaitu usia 20-65 tahun keatas berjumlah 5601 orang. Desa Girimulya sendiri merupakan desa yag memiliki mayoritas penduduknya bekerja sebagai pedagang, sehingga dari tingkat kemakmuran ekonomi masyarakat desa Girimulya sendiri telah cukup baik (Statistik Desa Girimulya, 2015).
Dalam perkembangan teknologi informasi yang semakin pesat, akan semakin terasa pentingnya untuk sebuah desa mengetahuipotensi yang dimilikinya dan tentu juga untuk mengenalkan seluruh potensinya ke seluruh wilayah Indonesia. Sebagai basis ekonomi, desa mempunyai aset-aset ekonomi seperti SDM, hutan, kebun, sawah, kerajinan, pantai, sungai, pasar dan potensi lainnya yang dalam hal ini penting sekali agar dapat diakses secara luas dalam rangka pengembangan desa itu sendiri.

Kebutuhan informasi secara luas mendorong peningkatan pengaksesan website yang berisi informasi sesuai dengan kebutuhan. Sebagaimana yang diungkapkan oleh Retnani (2013) tentang pentingnya website yang semakin berkembang pada saat ini tidak hanya digunakan untuk penyampaian informasi yang formal. Beberapa website menawarkan informasi informal berupa social network, belanja online, multimedia, dan masih banyak lagi. Pada tahun 1995, Georgia Tech menerbitkan hasil survei bahwa $63,6 \%$ para pengguna website memilih mengakses entertainment, $11.1 \%$ di antaranya menggunakannya untuk berbelanja. Hal ini menjelaskan bahwa cakupan informasi dari website semakin meluas.

Lebih jauh lagi Retnani (2003) mengungkapkan bahwa website saat ini menjadi salah satu service yang dijadikan sarana untuk mempublikasikan informasi. Tujuan dari penggunaan website ini memberikan kemungkinan bahwa adanya perbedaaan gender menyebabkan pengaruh dalam website, khususnya pada accessibility.

Selain itu beraneka ragamnya teknologi yang dapat digunakan dalam mengakses informasi di website ini, tentu akan berpengaruh terhadap perilaku informasi, khususnya penerimaan terhadap teknologi penyedia sumber informasi yang dimanfaatkan oleh masyarakat yang ada di desa. Untuk itu perlu dilakukan 


\section{3-213 | HARKAT: Media Komunikasi Islam Tentang Gender dan Anak, 11 (2), 2015}

usaha-usaha untuk mengetahui faktor-faktor apa yang berpengaruh atas penerimaan masyarakat terhadap pengembangan WEB desa ini.

Salah satu model penerimaan terhadap teknologi yang paling sesuai sampai sekarang adalah model Technology Acceptance Model (TAM). TAM adalah teori sistem informasi yang membuat model tentang bagaimana seseorang menerima dan menggunakan teknologi sistem informasi. Model penerimaan teknologi ini memperkenalkan dua variabel kunci yaitu, persepsi kegunaan dan persepsi kemudahan penggunaan (Davis, 1989).

Selanjutnya hasil penelitian ini akan memfokuskan pada pemanfaatan TAM sebagai kerangka teoritis untuk menyelidiki pengaruh faktor gender atas penerimaan masyarakat desa Girimulya terhadap perilaku pencarian informasi peluang usaha di WEB desa.

Permasalahan utama dalam penelitan ini adalah "Mengapa masih terdapat perbedaan dalam perilaku pencarian infomasi peluang usaha di WEB desa dilihat dari perspektif gender?" Untuk itu dalam kesempatan ini penulis mencoba membatasi lingkup penelitian ini pada faktorpersepsi kemudahan penggunaan, persepsi kegunaan, dan niat penggunaan WEB desa dalam perspektif gender bagi masyarakat desa Girimulya dalam mencari informasi peluang usaha.

Beberapa pertanyaan yang muncul, antara lain:

1. Apakah ada perbedaan yang signifikan antara persepsi kemudahan penggunaan, persepsi kegunaan, dan niatpenggunaan WEB desa dalam perspektif gender bagi masyarakat desa Girimulya dalam mencari informasi peluang usaha?

2. Seberapa besar pengaruh antara persepsi kemudahan penggunaan, persepsi kegunaan, dan niat penggunaan WEB desa dalam perspektif gender bagi masyarakat desa
Girimulya dalam mencari informasi peluang usaha baik secara sendiri (parsial) ataupun secara gabungan (simultan)?

\section{Landasan Teori}

Salah satu metode yang dapat digunakan untuk menganalisis besar serta pengaruh perbedaan antara pria dan wanita pada domain tertentu adalah Technology Acceptance Model (TAM). TAM sebenarnya diadopsi dari model Theory of Reasoned Action (TRA) yaitu teori tindakan yang beralasan bahwa reaksi dan persepsi seseorang terhadap sesuatu akan menentukan sikap dan perilaku orang tersebut (Retnani, 2012).

Konsep TAM pertama kali dikembangkan oleh Davis pada tahun 1986 dengan menawarkan sebuah teori sebagai landasan untuk mempelajari dan memahami perilaku pemakai dalam menerima dan menggunakan sistem informasi (Davis, 1986; Davis, Bagozzi dan Washaw, 1989). Konsep ini merupakan salah satu teori tentang penggunaan sistem teknologi informasi yang dianggap sangat berpengaruh dan umumnya digunakan untuk menjelaskan penerimaan individual terhadap penggunaan sistem teknologi informasi sebagai model penerimaan teknologi (Lambertus, 2012).

Davis dkk. (1989) menjelaskan bahwa alasan pertama seseorang berkeinginan untuk mengunakan sebuah teknologi informasi karena dia percaya bahwa perangkat tersebut dapat meningkatkan kinerjanya, yang selanjutnya disebut variabel persepsi kegunaan (perceived usefulness).Alasan yang kedua bahwa selain berguna perangkat tersebut juga harus mudah digunakan. Karena belum tentu orang tersebut mau menggunakan perangkat tersebut dengan alasan tidak mudah menggunakannya.Dengan demikian varibel kedua yang mempengaruhi penerimaan seseorang terhadap penggunaan sebuah teknologi dipengaruhi juga oleh persepsi 
kemudahan penggunaannya (perceived ease of use).

Dalam hal ini Davis dkk. (1989) menjelaskan bahwa TAM merupakan sebuah model yang diadaptasi dari TRA yang dikhususkan untuk model penerimaan pengguna terhadap sistem informasi. Tujuan utamanya adalah untuk menyediakan sebuah pijakan untuk menyelidiki pengaruh faktor-faktor kepercayaan internal, sikap dan minat. TAM diformulasikan untuk tujuan tersebut dengan cara mengidentifikasi sejumlah variabel penting yang berhubungan dengan pengetahuan dan sikap terhadap penerimaan komputer, dan dengan menggunakan TRA sebagai teori dasarnya untuk menggambarkan hubungan antar variabel tersebut.

Model TRA dapat diterapkan karena keputusan yang dilakukan individu untuk menerima suatu teknologi sistem informasi merupakan tindakan sadar yang dapat dijelaskan dan diprediksi oleh minat perilakunya.TAM menambahkan dua konstruk utama ke dalam model TRA seperti digambarkan di bawah ini.Dua konstruk utama ini adalah persepsi kegunaan (perceived usefulness) dan persepsi kemudahan penggunaan (perceived ease of use). TAM berargumen bahwa penerimaan individual terhadap sistem teknologi informasi ditentukan oleh dua konstruk tersebut (Jogiyanto, 2007).

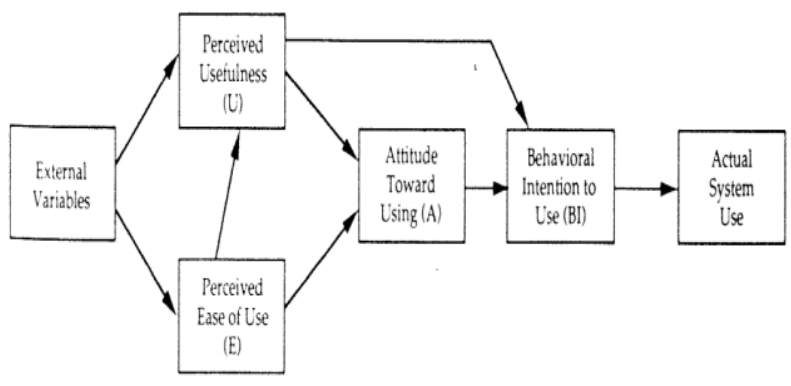

Gambar 1. Model TAM

(Sumber: Davis, Bagozzi dan arshaw,1989)
Selanjutnya penjelasan keenam konstruk yang sudah terbentuk tersebut dapat digambarkan dalam penjelasan berikut ini (Davis dkk., 1989; Jogianto, 2007):

1) Variabel Eksternal (EV)

Variabel ini adalah variabel luar yang mempengaruhi kemudahan dan manfaat dari sebuah sistem. Sebenarnya variabel eksternal merupakan penentu utama dalam menentukan kemudahan penggunaan teknologi (PEOU), seperti yang dijelaskan oleh Davis dkk.

2) Persepsi Kegunaan (PU)

Konstruk yang pertama ini didefinisikan sebagai sejauhmana seseorang percaya bahwa menggunakan suatu teknologi akan meningkatkan kinerja pekerjaannya ("as the extent to which a person believes that using a technology will enhance her or his performance."). Artinya, jika seseorang merasa percaya bahwa sistem informasi berguna maka dia akan menggunakannya. Sebaliknya, jika merasa percaya bahwa sistem informasi kurang berguna dia tidak akan menggunakannya. Dengan kata lain konstruk ini merupakan suatu kepercayaan (belief) tentang proses pengambilan keputusan.

3) Persepsi Kemudahan Penggunaan (PEOU)

Konstruk yang kedua dari TAM adalah persepsi kemudahan penggunaan (perceived ease of use) yang didefinisikan sebagai sejauh mana seseorang percaya bahwa menggunakan teknologi akan bebas dari usaha ("is the extent to which a person beleives that using a technology will be free efort"). Artinya, jika seseorang merasa percaya bahwa bahwa sistem informasi mudah digunakan maka dia akan menggunakannya. Sebaliknya, jika seseorang merasa percaya bahwa sistem tidak mudah digunakan maka dia tidak akan menggunakannya. 


\section{5-213 | HARKAT: Media Komunikasi Islam Tentang Gender dan Anak, 11 (2), 2015}

4) Sikap terhadap Perilaku (ATU)

Sikap terhadap perilaku (attitude toward behavior) didefinisikansebagai perasaan positif atau negatif dari seseorang jika harus melakukan perilaku yang ditentukan ("an individual's positive or negative feelings about performing the target behavior.")

5) Minat Perilaku (BI)

Minat perilaku (behavioral intention) adalah suatu keinginan (minat) seseorang untuk melakukan suatu perilaku yang tertentu. Seseorang akan melakukan suatu perilaku (behavior) jika mempunyai keinginan atau minat untuk melakukannya.

6) Perilaku Nyata (AU)

Perilaku Nyata (behavior) adalah tindakan yang dilakukan oleh seseorang.Dalam konteks penggunaan sistem teknologi informasi, perilaku adalah penggunaan sesungguhnya (actual use) dari teknologi.

Sebuah penelitian dengan model TAM tentang perbedaan gender di masyarakat Indonesia dalam penerimaan penggunaan Internet yang telah dilakukan oleh Wahid (2007) menggambarkan bahwa penyesuaian penggunaan internet pada gender wanita lebih cenderung dipengaruhi oleh faktor konstruk persepsi kemudahan penggunaan (PEOU). Sebaliknya pada gender pria lebih dipengaruhi oleh faktor persepsi kegunaan (PU).

Lebih jauh lagi Wahid (2007) menjelaskan bahwa terdapt perbedaan pola pemakaian internet antara gender pria dan wanita ini. Dalam hal ini dijelaskan bahwa porsi penggunaan internet untuk chatting dan kegiatan yang berhubungan dengan studi lebih besar dilakukan oleh wanita dari pada pria. Sedangkan penggunaan internet untuk membaca berita online, mengevaluasi dan mengunduh perangkat lunak, belanja, hiburan, mencari pekerjaan, dan mengunjungi situs berbau porno lebih banyak dilakukan oleh pria dari pada wanita.

Penelitian lainnya yang berhubungan dengan penggunaan internet dalam persfektif gender ini telah dilakukan oleh Retnani. Berdasarkan hasil pengujian, model TAMGender pada responden yang bekerja menggambarkan bahwa pada saat ini pengaruh gender terhadap accessibility website pada kategori website news, website social network, dan website internal kantor tidak memberikan pengaruh yang besar. Hasil ini berbanding terbalik untuk responden yang tidak atau sedang tidak bekerja. Pada responden yang tidak atau sedang tidak bekerja, hasil yang didapatkan adalah pengaruh gender terhadap accessibility website pada kategori website news dan website social network memberikan pengaruh yang cukup besar (Retnani, 2012).

\section{METODE PENELITIAN}

Metode kuantitatif yang digunakan dalam penelitian ini mencoba untuk mengukur aspekaspek perilaku mana dalam persfektif gender yang paling berbengaruh terhadap perilaku pencarian informasi peluang usaha di WEB oleh masyarakat desa Girimulya. Teknik penentuan sampeldilakukan melalui random sampling terhadap 100 orang warga (50 pria dan 50 wanita) dengan menyebarkan kuesioner yang telah dibuat berdasarkan konstruk-konstruk yang sudah terbentuk dalam model TAM yang disederhanakan. Pengambilan data dilakukan dari tanggal 28 s/d 30 Agusutus 2015 dengan bantuan 17 mahasiswa peserta KKN.

Selanjutnya untuk kategori pengukuran konstruk tersebut, peneliti menggunakan skala likert dari $1=$ sangat tidak setuju, hingga $4=$ sangat setuju. Nilai rata masing-masing responden dapat dikelompokkan ke dalam kelas interval, karena data ini merupakan data ordinal sehingga skala data harus interval. Interval 
merupakan kisaran jawaban responden yang diperoleh melalui selisih nilai maksimal dengan minimum dibandingkan jumlah kelas yaitu (Tony, 2012):

Tabel 1. Hasil Uji Validitas dan Reliabilitas

\begin{tabular}{|c|c|c|c|c|}
\hline \multicolumn{5}{|c|}{ Item-Total Statistics } \\
\hline & $\begin{array}{l}\text { Scale Mean if Item } \\
\text { Deleted }\end{array}$ & $\begin{array}{l}\text { Scale Variance if } \\
\text { Item Deleted }\end{array}$ & $\begin{array}{l}\text { Corrected Item- } \\
\text { Total Correlation }\end{array}$ & $\begin{array}{c}\text { Cronbach's Alpha if Item } \\
\text { Deleted }\end{array}$ \\
\hline PEOU1 & 52.26 & 74.982 & .673 & .930 \\
\hline PEOU2 & 52.37 & 73.205 & .732 & .928 \\
\hline PEOU3 & 52.11 & 75.978 & .570 & .932 \\
\hline PEOU4 & 52.02 & 76.767 & .502 & .933 \\
\hline PEOU5 & 52.15 & 73.725 & .685 & .929 \\
\hline PEOU6 & 52.15 & 75.644 & .559 & .932 \\
\hline PEOU7 & 52.08 & 77.589 & .521 & .933 \\
\hline PU1 & 52.16 & 74.802 & .670 & .930 \\
\hline PU2 & 52.09 & 76.042 & .555 & .932 \\
\hline PU3 & 52.13 & 74.801 & .639 & .930 \\
\hline PU4 & 52.16 & 73.631 & .711 & .929 \\
\hline PU5 & 52.18 & 74.614 & .716 & .929 \\
\hline PU6 & 52.10 & 72.576 & .734 & .928 \\
\hline PU7 & 52.18 & 73.745 & .714 & .929 \\
\hline BI1 & 52.03 & 75.464 & .599 & .931 \\
\hline $\mathrm{BI} 2$ & 52.12 & 75.339 & .642 & .930 \\
\hline $\mathrm{BI} 3$ & 52.02 & 74.868 & .685 & .929 \\
\hline BI4 & 51.92 & 77.105 & .621 & .931 \\
\hline
\end{tabular}

Interval :Nilai maksimal - nilai minimum

$$
\text { Jumlah kelas }
$$

Interval : $\underline{4-1} \mathbf{0}, 75$

$$
4
$$

Berdasarkan informasi tersebut, maka dapat ditentukan skala distribusi pendapat responden sebagai berikut:
a. Nilai sebesar $1,00-1,74=$ sangat rendah
b. Nilai sebesar $1,75-2,49=$ rendah
c. Nilai sebesar $2,50-3,24=$ tinggi
d. Nilai sebesar $3,25-4,00=$ sangat tinggi

Untuk mengetahui konsistensi dan akurasi data yang dikumpulkan dari penggunaan instrumen dilakukan uji validitas terhadap 18 pertanyaan dengan menggunakan hasil korelasi Corrected item total pada Tabel 1.

Tabel 1 di atas menunjukan bahwa seluruh pertanyaan yang diajukan memiliki nilai Corrected item total correlation ( $\mathrm{r}$ hitung) lebih besar dari $\mathrm{r}$ tabel 0,195 dengan signifikansi 0,5 pada uji 2 sisi, di mana $N=100 / d f=98$. Dengan demikian semua pertanyaan tersebut adalah valid.

Sedangkan, uji reliabilitas dilakukan dengan pendekatan internal consistency reliability yang menggunakan Cronbach Alpha untuk mengidentifikasikan seberapa baik itemitem dalam kuesioner berhubungan antara satu dengan yang lainnya. Pedoman alat ukur dikatakan reliable apabila nilai Cronbach Alpha sebesar 0.60 atau lebih. Berdasarkan tabel 1 di atas dapat diketahui bahwa semua pertanyaan memiliki nilai Cronbach Alpha di atas 0,90 dengan demikian semua pertanyaan yang diajukan dalam penelitian adalah reliable.

\section{Hasil Penelitian dan Pembahasan}

Hasil temuan data diuji dan dianalisa dengan menggunakan Statistical Package for 
Social Sceince (SPSS) versi 22. Adapun analisa data yang digunakan dalam penelitian ini adalah:

1. Hasil Uji Deskriptif responden

Uji Deskriptif responden digunakan untuk memberikan informasi mengenai karakteristik responden dari masing - masing sesuai dengan jenis kelamin responden yang diukur dengan skala nominal. Berikut ini (Tabel 2) adalah rangkuman data mengenai karakteristik responden.

Tabel 2 memberikan informasi tentang deskripsi statistik demografi responden yang di dalamnya dijelaskan mengenai frekuensi silang antara jenis kelamin dengan aspek-aspek lainnya. Dari hasil tersebut dapat diketahui jumlah responden yang berumur di atas 20 tahun sekitar 89 orang, pria (46 orang) dan wanita (42 orang). $\mathrm{Hal}$ ini berarti gambaran responden dalam penelitian ini $89 \%$ termasuk ke dalam kategori produktif kerja.

Selanjutnya proporsi terbesar responden (77\%) untuk pendidikan ada pada tingkat SMA ke atas. Dalam hal ini pria 44 orang dan wanita 33 orang. Sedangkan untuk proporsi jenis pekerjaan paling tinggi ada pada pilihan kantor swasta 39\%, dan peringkat terendah pada pilihan pekerjaan petani $8 \%$. Kemudian proporsi untuk jenis alat yang digunakan untuk mengakses internet ada pada pilihan HP, dimana antara pria dan wanita selisihnya hanya terpaut 1 sebagaimana halnya pada jenis pekerjaan. Selain itu dari seluruh responden (100 orang) yang mengisi kuesioner ini hanya 1 orang wanita yang belum mengakses internet pada saat penelitian ini dilakukan. Artinya hampir 100\% sampling yang ditemui telah mengakses internet.

Tabel 2. Data Demografi Responden

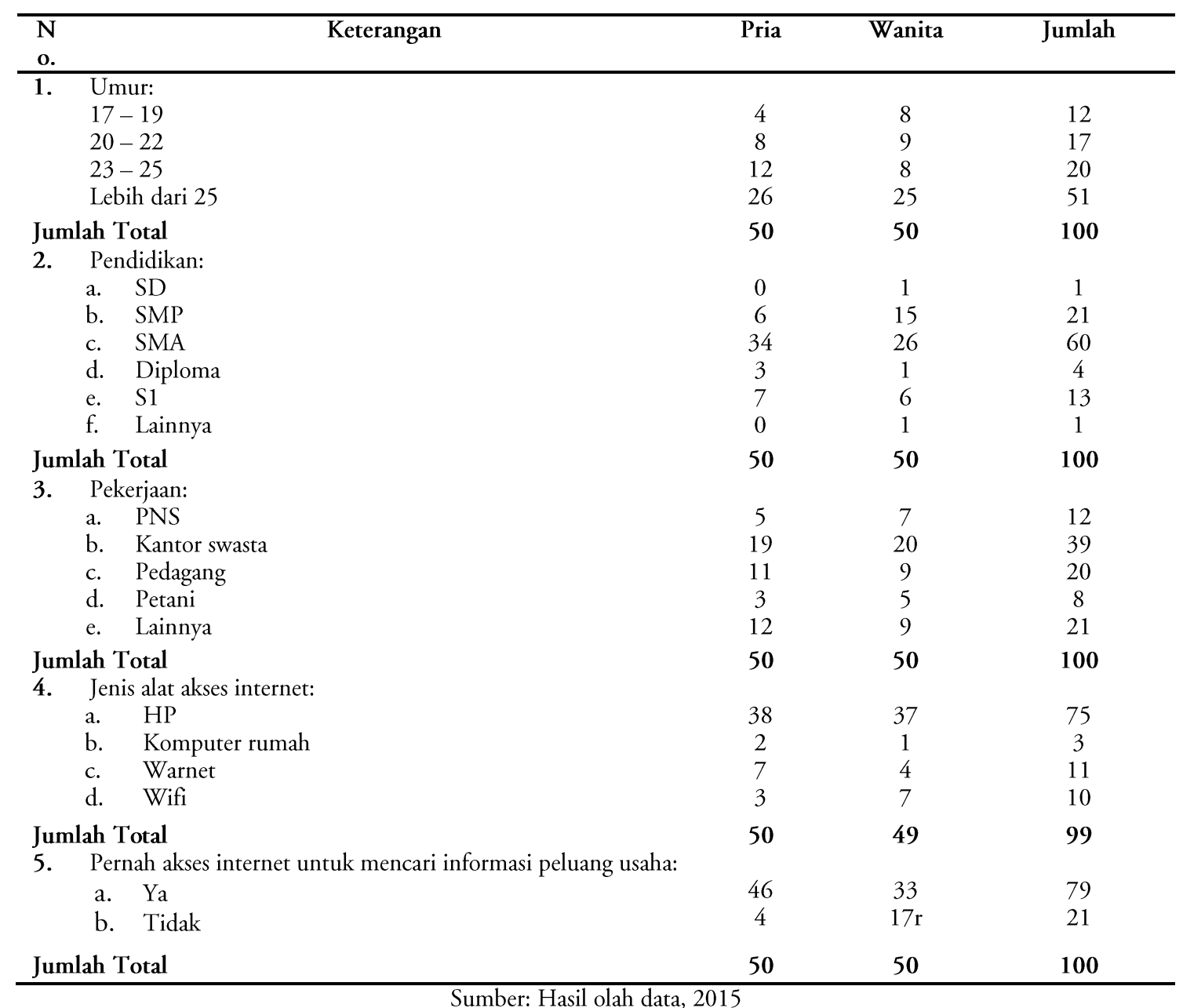

Sumber: Hasil olah data, 2015 
Tabel 3. Nilai Rata-RataPenerimaan Responden

\begin{tabular}{llll}
\hline No. & \multicolumn{1}{c}{ Konstruk } & \multicolumn{2}{c}{ Jenis Kelamin } \\
\cline { 3 - 4 } 1. & $\begin{array}{l}\text { Persepsi Kemudahan } \\
\text { Pria }\end{array}$ & 3.07 & Wanita \\
2. & $\begin{array}{l}\text { Penggunaan (PEOU) } \\
\text { Persepsi Kegunaan }\end{array}$ & 3.17 & 2.93 \\
3. PU) & $\begin{array}{l}\text { Niat untuk Penggunaan } \\
\text { (BI) }\end{array}$ & 3.27 & 3.07 \\
\hline
\end{tabular}

Sumber: Hasil olah data, 2015

Tabel 4. Hasil Uji Multikolineritas

Coefficients $^{\mathrm{a}}$

\begin{tabular}{|c|c|c|c|c|c|c|c|c|}
\hline \multirow[b]{2}{*}{ Model } & & \multicolumn{2}{|c|}{ Unstandardized Coefficients } & \multirow{2}{*}{$\begin{array}{c}\begin{array}{c}\text { Standardized } \\
\text { Coefficients }\end{array} \\
\text { Beta }\end{array}$} & \multirow[b]{2}{*}{$t$} & \multirow[b]{2}{*}{ Sig. } & \multicolumn{2}{|c|}{ Collinearity Statistics } \\
\hline & & $B$ & Std. Error & & & & Tolerance & VIF \\
\hline \multirow[t]{3}{*}{1} & (Constant) & 2.991 & .720 & & 4.152 & .000 & & \\
\hline & KEMUDAHAN & .068 & .056 & .118 & 1.217 & .227 & .349 & 2.865 \\
\hline & KEGUNAAN & .387 & .051 & .729 & 7.550 & .000 & .349 & 2.865 \\
\hline
\end{tabular}

a. Dependent Variable: NIAT

Sumber: Hasil olah data, 2015

Tabel 5. Hasil Uji Keofisien

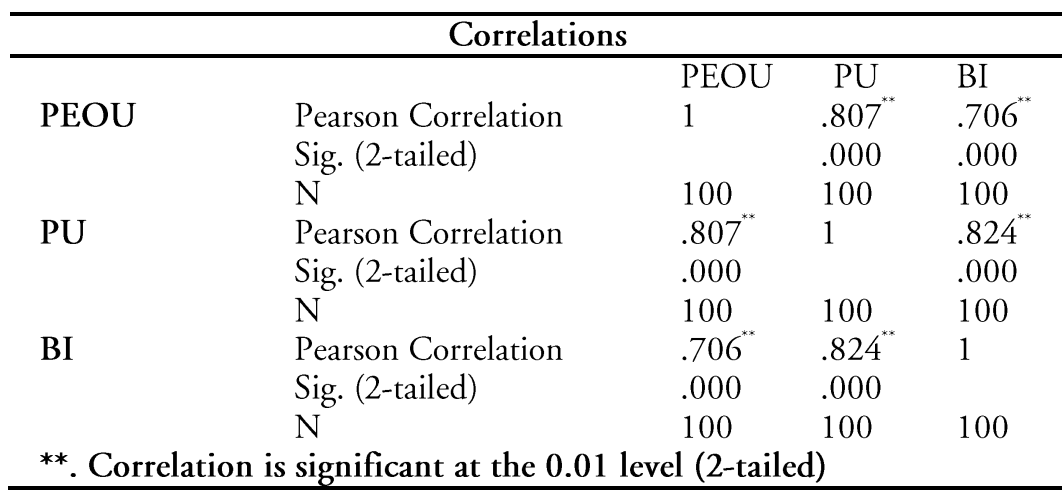

Sumber: Hasil olah data, 2015.

Data selanjutnya menjelaskan bahwa dari responden yang diteliti ini 79\% pernah akses internet untuk mencari peluang usaha, pria 46 orang dan wanita 33 orang. Hal ini menunjukan bahwa dari 50 responden untuk masing-masing jenis kelamin, pada kalangan pria menunjukan tingkat lebih tinggi penerimaannya terhadap keberadaan internet (WEB) sebagai sarana untuk mencari peluang usaha, yaitu $92 \%$, sedangkan pada kalangan wanita adalah $66 \%$.

Pada tabel 3 di atas digambarkan nilai ratarata masing-masing konstruk untuk tiap gender. Berdasarkan informasi tersebut, maka dapat diketahui bahwa konstruk PEOU dan PU pada gender pria mempunyai rata-rata tinggidan ini sama halnya pada gender wanita. Sedangkan nilai rata-rata konstruk niat untuk penggunaan terdapat perbedaan pada gender pria lebih tinggi dibanding gender wanita.

Dari gambaran tersebut dapat disimpulkan bahwa secara umum perilaku yang telah dibentuk berdasarkan konstruk-konstruk di atas menunjukan nilai rata-rata tinggi. Hanya saja pada konstruk niat untuk penggunaan (BI) pada gender pria lebih tinggi dari pada wanita. Dengan demikian masih ada perbedaan antara 
pria dan wanita pada perilaku niat mencari informasi peluang usaha di WEB desa.

2. Hasil Uji Normalitas dan Multikolinieritas

Uji normalitas pada penelitian ini bertujuan untuk menguji apakah dalam model regresi variabel terikat dan variabel bebas keduanya mempunyai distribusi normal atau tidak.

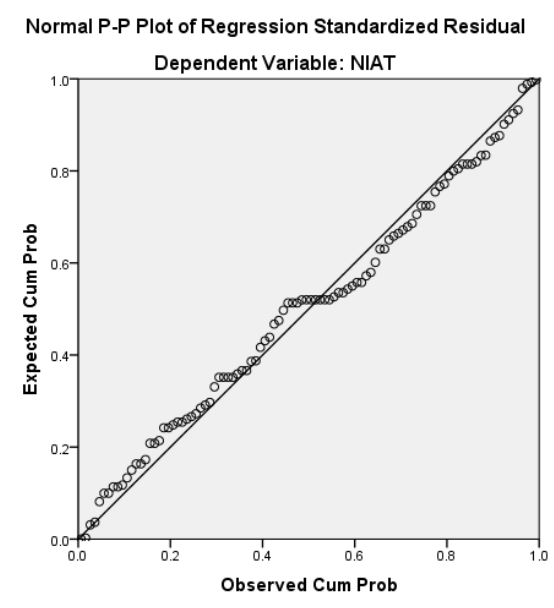

Gambar 1. Hasil Uji Normalitas

Sumber: Hasil olah data, 2015

Pada gambar 1 dapat dijelaskan hubungan persepsi kemudahan penggunaan (PEOU) dan persepsi kegunaan (PU) terhadap niat (BI) menunjukan pola distribusi normal di mana data menyebar di sekitar garis diagonal. Hal ini menunjukan bahwa model regresi telah memenuhi asumsi normalitas.

Sedangkan uji multikolinieritas merupakan uji yang ditujukan untuk menguji apakah pada model regresi ditemukan adanya korelasi antar variabel bebas. Untuk melihat ada tidaknya gejala multikolinieritas dengan melihat nilai Variance Inflation Factor (VIF) dan Tolerance pada tabel 4.

Dari hasil uji di atas dapat diketahui bahwa nilai Tolerance kedua variabel lebih dari 0,10 dan VIF kurang dari 10, maka dapat disimpulkan bahwa tidak terjadi multikolineiritas antar variabel bebas dan dapat digunakan dalam penelitian ini.

\section{Hasil Uji Korelasi}

Untuk melihat hasil uji korelasi dapat dilihat dari hasil uji koefisien determinasi pada tabel 5.

Dari hasil keluaran di atas dapat dijelaskan bahwa korelasi antar persepsi kemudahan penggunaan terhadap persepsi kegunaan $(\mathrm{PEOU} \rightarrow \mathrm{PU}$ ) didapat nilai 0,807; dan PEOU $\rightarrow$ BI adalah 0,706. Karena koefisien mendekati angka 1, maka dapat disimpulkan bahwa antara PEOU terhadap PU dan PEOU terhadap BI memiliki hubungan yang sangat kuat dan positif. Hal ini sebagaimana dijelaskan oleh Jonathan (2006) pedoman untuk memberikan interpretasi koefisien korelasi sebagai berikut:

$0,00-0,25=$ korelasi sangat lemah

$>0,25-0,5=$ korelasi cukup

$>0,5-0,75=$ korelasi kuat

$>0,75-1=$ korelasi sangat kuat

Artinya, jika persepsi kemudahan penggunaan meningkat (PEOU), maka persepsi kegunaan (PU) meningkat pula dan sebaliknya. Selanjutnya, nilai hubungan PEOU terhadap BI $(0,706)$ dan PU terhadap BI $(0,824)$. Artinya kedua hubungan tersebut juga memiliki angka keofisien yang positif kuat dan sangat kuat.

4. Hasil Uji Hipotesis

Uji hipotesis dalam penelitian ini menggunakan analisis jalur (path analysis), yaitu suatu teknik analisis statistik yang dikembangkan dari analisis regresi berganda. Metode ini digunakan untuk menguji kuat tidaknya korelasi dua atau lebih variabel terikat terhadap variabel bebas dengan nilai signifikannya sebesar 0,05.

Dalam penelitian ini dibuat 2 persamaan substruktural dari model TAM Gender yang disederhanakan berikut ini:

Model persamaan substruktural 1: $X_{2}=p x_{2} x_{1}+$ $p x_{2} \varepsilon_{1}$

Model persamaan substruktural 2: $Y_{1}=p y_{1} x_{1}+$ $p y_{1} x_{2}+p y_{1} \varepsilon_{2}$ 


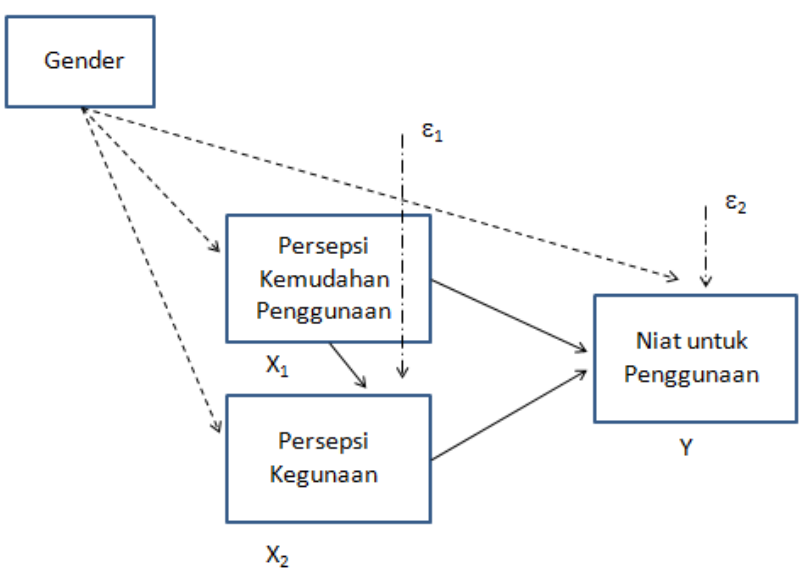

Gambar 2. Model Penelitian

Keterangan:

$\mathrm{Y}_{1} \quad=$ Niat untuk Penggunaan

$\mathrm{X}_{1} \quad=$ Persepsi Kemudahan Penggunaan

$\mathrm{X}_{2} \quad=$ Persepsi Kegunaan

$P \quad=$ Koefisien Jalur (Path Coefficient)

$\varepsilon \quad=$ Error

\section{Hasil Koefisien Determinasi}

Untuk melihat besarnya pengaruh secara simultan pada masing-masing konstruk dalam persfektif gender ini dapat dilihat pada hasil perhitungan model summary, khususnya angka $R$ square pada tabel 6 .

Pada model 1 menunjukan bahwa pengaruh persepsi kemudahan penggunaan (PEOU) terhadap persepsi kegunaan (PU) secara simultan pada gender pria sebesar 0,576 dan wanita sebesar 0,715. Angka tersebut mempunyai arti bahwa pengaruh PEOU terhadap PU pada gender pria adalah 57,6\%, sisanya $42,4 \%(100 \%-57,6 \%)$ dipengaruhi faktor lain di luar penelitian ini. Sebaliknya pada gender wanita adalah $71,5 \%$, sisanya $28,5 \%$ dipengaruhi faktor lainnya. Gambaran angka ini menunjukan bahwa pengaruh persepsi kemudahan penggunaan terhadap persepsi kegunaan secara simultan pada gender wanita lebih tinggi dibandingkan pria.

Selanjutnya, pada model 2 menunjukan bahwa pengaruh PEOU dan PU secara simultan terhadap BI pada gender pria sebesar 0,524 dan wanita sebesar 0,808 ; sisanya pada pria sebesar 0,476 dan wanita sebesar 0,192 dipengaruhi oleh faktor lainnya di luar penelitian ini. Pada model 2 ini pengaruh PEOU dan PU secara simultan terhadap BI pada gender wanita lebih tinggi $80,8 \%$ berbanding $52,4 \%$ dari pria.

\section{Uji F}

Uji F dikenal dengan Uji serentak atau uji Model/Uji Anova, yaitu uji untuk untuk menguji apakah model regresi yang kita buat $\mathrm{baik} /$ signifikan atau tidak baik/non signifikan. Jika model signifikan maka model bisa digunakan untuk prediksi/ peramalan, sebaliknya jika non/tidak signifikan maka model regresi tidak bisa digunakan untuk peramalan. Uji F pada penelitian ini menggunakan tingkat signifikan 0,05 dengan membandingkan angka $F$ penelitian dengan $\mathrm{F}_{\text {tabel }}(2,409)$.

Tabel 6 Hasil Uji Koefisien Determinasi (Model Summary)

\begin{tabular}{|c|c|c|c|c|c|c|c|c|}
\hline \multirow[t]{2}{*}{ Model } & \multicolumn{2}{|c|}{$\mathrm{R}$} & \multicolumn{2}{|c|}{ R Square } & \multicolumn{2}{|c|}{ Adjusted R Square } & \multicolumn{2}{|c|}{$\begin{array}{l}\text { Std. Error of the } \\
\text { Estimate }\end{array}$} \\
\hline & Pria & Wanita & Pria & Wanita & Pria & Wanita & Pria & Wanita \\
\hline 1 & $.759^{\mathrm{a}}$ & $.846^{\mathrm{a}}$ & .576 & .715 & .576 & .709 & 2.180 & 2.428 \\
\hline 2 & $.724^{a}$ & $.899^{a}$ & .524 & .808 & .504 & .800 & 1.436 & .969 \\
\hline
\end{tabular}

Sumber: Hasil olah data, 2015 


\section{1-213 | HARKAT: Media Komunikasi Islam Tentang Gender dan Anak, 11 (2), 2015}

Tabel 7. Hasil Uji Anova

\begin{tabular}{ccccc}
\hline Model & \multicolumn{4}{c}{ Gender } \\
\cline { 2 - 6 } & \multicolumn{2}{c}{ Pria } & \multicolumn{2}{c}{ Wanita } \\
& F & Sig. & F & Sig. \\
$\mathbf{1}$ & 65.106 & $.000^{\mathrm{b}}$ & 120.401 & $.000^{\mathrm{b}}$ \\
$\mathbf{2}$ & 25.855 & $.000^{\mathrm{b}}$ & 98.852 & $.000^{\mathrm{b}}$ \\
\hline
\end{tabular}

Sumber: Hasil olah data, 2015

Tabel 8.Hasil Uji Coefficients

\begin{tabular}{|c|c|c|c|c|c|}
\hline \multirow[t]{3}{*}{ Model } & & \multicolumn{4}{|c|}{ Gender } \\
\hline & & \multicolumn{2}{|c|}{ Pria } & \multicolumn{2}{|c|}{ Wanita } \\
\hline & & $\mathbf{t}$ & Beta & t & Beta \\
\hline \multirow[t]{2}{*}{1} & (Constant) & & & & \\
\hline & Kemudahan & 8.069 & .759 & 10.973 & .846 \\
\hline \multirow[t]{3}{*}{2} & (Constant) & & & & \\
\hline & Kemudahan & 1.167 & .180 & .555 & .066 \\
\hline & Kegunaan & 3.737 & .577 & 7.032 & .842 \\
\hline
\end{tabular}

Sumber: Hasil olah data, 2015

Dari hasil penghitungan didapatkan angka $F_{\text {penelitan }}$ pada model 1 gender pria sebesar 65.106 dan wanita sebesar $120,401>\mathrm{F}_{\text {tabel }}$ sehingga $\mathrm{H}_{0}$ ditolak dan $\mathrm{H}_{1}$ diterima. Artinya, ada hubungan linear antara persepsi kemudahan penggunaan (PEOU) dengan persepsi kegunaan(PU) baik pada gender pria maupun wanita. Dengan demikian, model regresi di atas sudah layak dan benar.

Selanjutnya, pada model 2 baik pada gender pria maupun wanita masing-masing memiliki angka $\mathrm{F}_{\text {penelitian }}>\mathrm{F}_{\text {tabel }}$ sehingga $\mathrm{H}_{1}$ diterima, dan hal ini menunjukan bahwa ada hubungan yang linear antara persepsi kemudahan penggunaan (PEOU) dan persepsi kegunaan (PU) dengan niat untuk penggunaan (BI)baik pada gender pria maupun wanita. Sehingga model regresi 2 sudah layak dan benar.

\section{Uji T}

Uji $\mathrm{T}$ dikenal dengan uji parsial, yaitu untuk menguji bagaimana pengaruh masingmasing variabel eksogennya secara sendiri-sendiri (parsial) terhadap variabel endogennya. Uji ini dilakukan dengan membandingkan $t_{\text {penelitian }}$ dengan $t_{\text {tabel }}(1,980)$, sedangkan angka pengaruhnya dapat dilihat dari angka Beta.
Berdasarkan hasil penghitungan pada model 1, diperoleh angka $t_{\text {penelitian }}$ untuk pria sebesar 8.069 dan wanita sebesar 10,973> $t_{\text {tabel }}$ $(1,980)$ sehingga $\mathrm{H}_{0}$ ditolak dan $\mathrm{H}_{1}$ diterima. Artinya ada hubungan linier secara parsil antara persepsi kemudahan penggunaan (PEOU) dengan persepsi kegunaan (PU). Besarnya pengaruh pada PEOU terhadap PU pada gender pria sebesar 75,9\% dan wanita sebesar $84,6 \%$.

Selanjutnya pada model 2, diperoleh angka $\mathrm{t}_{\text {penelitian }}$ untuk pria sebesar 1,167 dan wanita sebesar $0,555<t_{\text {tabel }}(1,980)$ sehingga $H_{0}$ diterima dan $\mathrm{H}_{1}$ ditolak. Artinya secara parsial tidak ada hubungan linier antara persepsi kemudahan penggunaan (PEOU) dengan niat untuk penggunaan (BI) baik pada gender pria maupun wanita. Besarnya pengaruh pada PU terhadap BI pada gender pria sebesar $18 \%$ dan wanita sebesar $6,6 \%$.

Sedangkan untuk pengaruh PU terhadap BI pada gender pria sebesar 3,737 dan wanita $7,032>t_{\text {tabel }}(1,980)$ sehingga $H_{0}$ ditolak dan $H_{1}$ diterima. Artinya ada hubungan linier secara parsial antara persepsi kegunaan (PU) terhadap niat untuk penggunaan (BI). Besarnya pengaruh pada PU terhadap BI pada gender pria sebesar $57,7 \%$ dan wanita sebesar $84,2 \%$. 
Tabel 8. Hasil Uji Hipotesis

\begin{tabular}{lllllllll}
\hline Hipotesis & Hubungan & \multicolumn{2}{l}{ Hasil Uji T } & \multicolumn{2}{l}{ Nilai } \\
Pengaruh \\
& & \multicolumn{7}{c}{ Keterangan } \\
\cline { 3 - 8 } & & & Pria & Wanita & Pria & Wanita & Pria & Wanita \\
H1 & PEOU $\rightarrow$ & 8.069 & 10.973 & .759 & .846 & Diterima & Diterima \\
& PU & & & & & & \\
H2 & PEOU $\rightarrow$ & 1.167 & .555 & .180 & .066 & Ditolak & Ditolak \\
& BI & & & & & & \\
H3 & PU $\rightarrow$ BI & 3.737 & 7.032 & .577 & .842 & Diterima & Diterima \\
\hline
\end{tabular}

Sumber: Hasil olah data, 2015

Dari hasil analisis data di atas dapat digambarkan penerimaan dan penolakan terhadap hipotesis penelitian berikut ditampilkan pada tabel 8.

Secara umum hasil uji $\mathrm{T}$ pada hipotesis 1 menunjukan ada hubungan yang signifikan antara persepsi kemudahan penggunaan (PEOU) dan persepsi kegunaan (PU), dimana pada kedua nilai $\mathrm{t}_{\text {penelitian }}$ baik pada gender pria maupun wanita lebih besar dari $t_{\text {tabel }}$. Namun jika dilihat dari masing-masing angka yang dihasilkan, pengaruh PEOU terhadap PU pada gender wanita lebih besar dibandingkan pria. Angka ini menunjukan bahwa pengaruh persepsi kemudahan penggunaan terhadap persepsi kegunaan WEB desa sebagai sumber informasi peluang usaha bagi gender wanita lebih besar dibandingkan pria.

Perbedaan pengaruh pada hasil uji hipotesis 1 di atas, secara umum terjadi juga pada hasil uji hipotesis 3. Dimana pengaruh persepsi kegunaan (PU) terhadap niat untuk menggunakan (BI) WEB desa sebagai sumber informasi peluang usaha lebih besar pada gender wanita daripada pria.Dalam hal ini Wahid (2007) menjelaskan bahwa perbedaan ini sejalan dengan beberapa penelitian yang telah di lakukan di Amerika (Venkaatesh dan Morris, 2000; Hofsttede, 1997; Minton dan Schneider, 1971) di mana pengaruh persepsi kegunaan lebih cenderung dipengaruhi oleh gender wanita dari pada pria.

Lain halnya dengan hasil uji hipotesis 2 yang ditolak, pengaruh PEOU terhadap BI lebih besar pada gender pria dari pada wanita. Dengan demikian ada kecenderungan bahwa gender wanita berniat untuk menggunakan WEB desa dengan lebih mempertimbangkan faktor nilai kebermanfaatannya dibandingkan faktor kemudahan mengaksesnya. Jika WEB desa tersebut bermanfaat untuk mendapatkan peluang usaha, mereka akan menggunakannya sebagai sarana pencarian informasi tersebut.

\section{PENUTUP}

Berdasarkan penelitian yang dilakukan dari ketiga aspek perilaku (PEOU; PU; dan BI), terdapat perbedaan pada niat untuk penggunaan WEB desa bagi masyarakat desa Girimulya dalam mencari informasi peluang usaha, di mana gender pria lebih tinggi dibandingkan gender wanita. Perbedaan ini didapatkan karena ada kecenderungan pengaruh persepsi kegunaan yang lebih besar pada gender wanita terhadap niat untuk penggunaan WEB desa sebagai sarana peluang usaha.

Perbedaan angka pada aspek lainnya sangatlah kecil karena dari hasil yang diperoleh persebaran jawaban responden antara pria dan wanita tidak terdapat selisih yang jauh, dan hal 


\section{3-213 | HARKAT: Media Komunikasi Islam Tentang Gender dan Anak, 11 (2), 2015}

ini masih ada pada skala nilai yang sama antara 2,50 - 3,24 (tinggi). Hasil penelitian ini memberikan gambaran bahwa peluang yang sama antara proporsi gender pria dan wanita pada niat untuk penggunaan akan terjadi ketika pengembangan WEB desa yang dibangun dirasakan memiliki kebermanfaatan dalam mememuhi informasi peluang usaha.

Penelitian ini memiliki beberapa keterbatasan, yaitu, pertama, hasil yang diperoleh tidakdapat digeneralisasi karena homogenitas sampel yang digunakan yaitu masyarakat berasal dari satu desa saja. Kedua, jumlah sampel yang digunakan lebih kecil daripada jumlah sampel yang digunakan pada penelitianpenelitiansebelumnya.

\section{DAFTAR PUSTAKA}

Davis, Fred D. 1986. "A Technology Acceptance Model for Empirically Testing New End-User Information Systems: Theory and Results," doctoral dissertation, MIT Sloan School of Management, Cambridge, MA . http://dspace.mit.edu/handle/1721.1/1519 2

Davis, Fred D. 1989. "Perceived Usefulness, Perceived Ease of Use, and User Acceptance of Information Technology”.MIS Quarterly, Vol. 13, No. 3 (Sep., 1989), hal.319-340. Diakses di http://www.jstor.org/stable/249008 tanggal 13/2/2014.

Husein Umar. Metode Riset Perilaku Konsumen Jasa. (Jakarta: Ghalia Indonesia, 2003). Hal. 64.

Iskandar, Marzan. Teknologi dan kesetaraan gender dalam pembangunan nasional. Tersedia di

http://www.bppt.go.id/index.php/profil/organisa si/63-profil-tiem/1518-teknologi-dan- kesetaraan-gender-dalam-pembangunannasional/. Diakses tanggal 8/9/2015.

Jogiyanto, 2007. Sistem Informasi Keperilakuan, Yogyakarta: Andi Offset, hal. 111-112.

Lambertus P. Wairisal dan Nur Khusniyah I. 2012. "Analisis Perilaku Penggunaan Teknologi Informasi (Studi pada Dosen Universitas Pattimura Ambon)”. Jurnal Aplikasi Manajemen, Vol. 10, No. 4 Hal. 763.

Retnani, Windi Eka Yulia.2012. Pengaruh Perbedaan Gender terhadap WEB Accessibility dengan Menggunakan Technology Acceptance Model (TAM). Tersedia di http://dspace.unej.ac.id/ handle/123456789/1364. Diakses tanggal 8/9/2015.

Smarkola, Claudia. 2011. A Mixedmethodological technology adoption study. Dalam Timothy Teo. Technology Acceptance in Education: Research and Issues. Rotterdam: Sense Publishers.

Saraswati, Tumbu. 2013. Pengarusutamaan Gender dalam Kebijakan Pembangunan. Tersedia di http://www.komnasperemp uan.or.id/2013/11/pengarusutamaangender-dalam-kebijakan-pembangunan/. Diakses tanggal 8/9/2015.

Tony Wijaya. 2012. Praktis dan Simpel Cepat Menguasai SPSS 20 untuk Olah dan Interpretasi Data. Yogyakarta: Cahaya Atma Pustaka.

Wahid, Fathul. 2007. Using the Technology Adoption Model to Analyze Internet Adoption and Use among Men and Women in Indonesia. EJISDC. Vol. 32, No. 6. Hal. 1-8. Tersedia di http://www.ejisdc.org. Diakses tanggal 12/8/2015. 